\title{
The effect of Enterobius vermicularis infection (oxyuriasis) on eosinophil and IgE levels in allergic rhinitis
}

\author{
Fevzi Solmaz', Oğuzhan Dikici', Davut Akduman², Mehmet Haksever', İsmail Necati Hakyemez ${ }^{3}$, \\ Muhammed Yanilmaz
}

${ }^{1}$ Department of Otorhinolaryngology, University of Health Sciences, Bursa Yüksek Ihtisas Training and Research Hospital, Bursa, Turkey

${ }^{2}$ Department of Otorhinolaryngology, Düzce University School of Medicine, Düzce, Turkey

${ }^{3}$ Department of Infection Diseases, Bezmialem University School of Medicine, İstanbul, Turkey

${ }^{4}$ Department of Otorhinolaryngology, Bezmialem University School of Medicine, Istanbul, Turkey

DOI: $10.18621 /$ eurj.344495

\begin{abstract}
Objectives: Elevated levels of serum IgE and eosinophilia are the indicators of atopy and intestinal parasitic infections. We evaluated the effect of Enterobius vermicularis infection (enterobiasis) on blood eosinophil count and IgE levels in allergic rhinitis.

Methods: A total of 110 patients diagnosed with allergic rhinitis (with symptoms of rhinorrhea, itchy nose and nasal congestion) consisting of $41(37.27 \%)$ males and 69 (62.73\%) females were examined. Forty-one $(37.27 \%)$ patients with enterobiasis were selected as the study group. The remaining $69(62.73 \%)$ patients accepted as the control group.

Results: In the study group the mean serum total IgE level and mean serum eosinophil count were $393.10 \pm$ $159.83 \mathrm{IU} / \mathrm{mL}$ and $0.56 \pm 0.0410^{3} / \mathrm{mL}$, respectively. In the control group the mean serum total $\mathrm{IgE}$ level and mean serum eosinophil count were $236.91 \pm 63.55 \mathrm{IU} / \mathrm{mL}$ and $0.37 \pm 0.1210^{3} / \mathrm{mL}$, respectively. The difference between the two groups was statistically significant for serum total $\operatorname{IgE}$ levels $(p<0.05)$ but not for serum eosinophil count $(p>0.05)$. The correlation coefficients between serum total IgE level and eosinophil count were statistically insignificant $(p>0.05)$.

Conclusions: More comprehensive and long-term placebo-controlled studies should be performed in order to find the answer to the question of whether helminth infections play a role in allergic disease.
\end{abstract}

Keywords: Enterobius vermicularis infection, allergic rhinitis, serum IgE level, serum eosinophil count

Received: October 15, 2017; Accepted: December 17, 2017; Published Online: February 27, 2018

$\mathrm{E}$ levated levels of serum $\operatorname{IgE}$ and eosinophilia are the indicators of atopy, but intestinal parasitic infections may also play role in alterations of those parameters [1]. In atopic individuals, the secretion of IgE increases depending on type 1 immune response. Human and animal studies have revealed a relationship between allergy and parasitic infections [2]. Elevated serum total IgE levels indicate either chronic parasitic infection or atopy.

Interactions between serum IgE levels, eosinophil count and parasitic infections depend on the duration of infestation and the type of helminth [3]. This is common in the population with endemic helminthic infections $[4,5]$. It has been shown that persons with the highest total IgE levels are re-infected after the treatment of helminthic infections in endemic areas.

Address for correspondence: Fevzi Solmaz, MD., University of Health Sciences, Bursa Yüksek Ihtisas Training and Research Hospital, Department of Otorhinolaryngology, Emniyet Caddesi No:35, 16115 Yıldirım, Bursa, Turkey

E-mail: solmazfevzi@hotmail.com,Phone: +902242955000,Fax:+902243660416 
Such elevated levels of total IgE may be due to environmental factors rather than heredity [6]. On the other hand, experimental and epidemiological studies have provided conflicting results. The phagocytic ability of eosinophils is weaker than that of neutrophils and their major functions are seen after the activation of toxic granule secretion. The main function of eosinophils in the host defense system against parasites is to attach, immobilize and kill parasites. The granular proteins secreted from the activated eosinophils kill parasites but they may cause damage to some mammalian cells. They can then lead to tissue damage and cause asthma or other inflammatory disorders. The most common inflammatory conditions, such as bronchial asthma, allergic eye inflammation, chronic fatigue syndrome, parasitic and bacterial infections, atopic dermatitis, rhinitis, allergic middle ear effusion and autoimmune diseases accompany to the eosinophil activation [7].

$\operatorname{IgE}$ is important both for active immunity in type I hypersensitivity reactions (such as asthma, urticaria, and high fever) and against parasites called helminths. A strong correlation is observed between allergy and increased serum IgE levels. The evaluation of serum $\operatorname{IgE}$ levels is therefore useful in conditions such as allergic rhinitis, extrinsic asthma, urticaria, atopic eczema, and anaphylaxis.

Eosinophils are leukocytes that eliminate antigenantibody complexes and are capable of phagocytosis. The number of eosinophils increases in conditions such as allergy and parasitic disease. The granules of these leukocytes contain histamine at a rate of $33 \%$ in humans. The amount of IgE in mucosal secretions increases during helminthic infections and allergic diseases [7].

Enterobiasis (pinworm disease or threadworm) is caused by the small nematode Enterobius vermicularis. Prevalence rates up to $100 \%$ have been recorded in Northwestern Europe and the USA. It is probably the most common helminth to infect humans. $E$. vermicularis eggs have been displayed in a coprolite carbon dated to $7837 \mathrm{BC}$ in western Utah [8].

Routine examination of a fecal sample gives a positive diagnosis in only $5-15 \%$ of infected subjects [8]. The best way of diagnosis depends on identification of adult worms or eggs, or both - which can be visualized in perianal region, usually at night $[9,10]$. Application of a Sellotape strip to the perianal region is of value; when adherent (sticky side downwards) to a microscope slide, visualization of worms and eggs is straightforward (the debris is cleared with a drop of toluene). Three tests can detect $90 \%$ of infections while six consecutive negative results on separate days virtually exclude this diagnosis.

The aim of this study was to determine the effect of $E$. vermicularis infection (enterobiasis) on blood eosinophil count and IgE levels in allergic rhinitis, and to discuss the role of helminths in allergic rhinitis. We compared patients diagnosed with allergic rhinitis who were positive or negative for enterobiasis regarding IgE levels and eosinophil counts.

\section{METHODS}

Patients who presented to the Ear, Nose and Throat Clinic and diagnosed with Allergic Rhinitis were evaluated. Informed consent was received from all patients. The Ethical Committee Approval was received from the study center. The diagnosis of allergic rhinitis was established by patient's history, a positive prick test and elevated serum $\operatorname{IgE}$ levels (higher than $100 \mathrm{U} / \mathrm{mL}$ ). Patients diagnosed with both allergic rhinitis and enterobiasis was included in the study group. The diagnosis of enterobiasis was confirmed by 3 consecutive anal cellotape microscopy evaluations while 6 consecutive negative results were required to rule out enterobiasis. Feces microscopy was used to rule out other parasites and patients whose feces were positive for parasite eggs other than $E$. vermicularis were excluded.

After informed consent was received from the patients, a clinical history was taken and a physical examination including nasopharyngeal examination performed. A total of 110 patients diagnosed with allergic rhinitis (with symptoms of rhinorrhea, itchy nose and nasal congestion) consisting of 41 (37.27\%) males and $69(62.73 \%)$ females were included in the study. The $41(37.27 \%)$ patients with positive result for E. vermicularis eggs were selected as the study group. The remaining $69(62.73 \%)$ patients evaluated as the control group. Factors affecting allergy or atopy were ruled out with questions. We were unable to include a healthy control group and our control group consisted of the subjects with allergic rhinitis in whom 
Table 1. The demographic characteristics and laboratory findings of the patients.

\begin{tabular}{lccc}
\hline & $\begin{array}{c}\text { With } \text { E. vermicularis } \\
(\mathbf{n}=\mathbf{4 1})\end{array}$ & $\begin{array}{c}\text { Without } \text { E. vermicularis } \\
(\mathbf{n}=\mathbf{6 9})\end{array}$ & p \\
\hline Age (year) & $34.25 \pm 10.58$ & $34.94 \pm 10.84$ & $>0.05$ \\
Gender $(\mathbf{M} / \mathbf{F})$ & $13 / 28$ & $28 / 41$ & $>0.05$ \\
IgE $(\mathbf{I U} / \mathbf{m L})$ & $393.10 \pm 159.83$ & $236.91 \pm 63.55$ & $<0.05$ \\
Eosinophil count $\left(\mathbf{1 0}^{\mathbf{3}} / \mathbf{m L}\right)$ & $0.56 \pm 0.04$ & $0.37 \pm 0.12$ & $>0.05$ \\
\hline
\end{tabular}

Data are shown as mean \pm standard deviation or number

E. vermicularis eggs were not found on microscopy.

Patients who had used oral antibiotics or corticosteroids and inhaled corticosteroids within the prior 30 days were excluded from the study. A detailed history was taken and an examination was performed and the patients were referred for blood and stool samples.

The samples were evaluated for E. vermicularis eggs with a light microscope at a magnification of $10 \times$ and $40 \times$ by an infectious diseases specialist. Eosinophil levels above $0.5103 / \mathrm{ml}$ in the complete blood count were considered as positive or elevated. The association of total serum IgE levels and eosinophil count with the presence of $E$. vermicularis infections or allergic rhinitis was investigated.

Single-dose mebendazole treatment with a repeated dose a week later used for treatment. The pretreatment results were also compared with the post-treatment results.

The relationship between total serum $\operatorname{IgE}$ and eosinophil count was analyzed using Pearson's Correlation and Spearman's rank tests due to the nonnormal distribution of the variables. These analyses can potentially create a basis for treatment. All data were analyzed using the SPSS for Windows v.16.0 software by IBM, USA.

\section{Statistical Analysis}

The relationship between total serum $\operatorname{IgE}$ and eosinophil count was analyzed using Pearson's Correlation and Spearman's rank tests due to the nonnormal distribution of the variables. These analyses can potentially create a basis for treatment. All data were analyzed using the SPSS for Windows v.16.0 software by IBM, USA.

\section{RESULTS}

The 110 patients included in the study consisted of $41(37.27 \%)$ males and $69(62.73 \%)$ females. The average age was $32.50 \pm 7.42$ years. The blood serum IgE levels were 138.00 to $850.00 \mathrm{IU} / \mathrm{mL}(282.69 \pm$ $129.93 \mathrm{IU} / \mathrm{mL}$ ). Our patients were selected from subjects with allergic rhinitis and elevated serum $\operatorname{IgE}$ levels. Table 1 presents the total IgE level, eosinophil count, and gender and age values of the allergic rhinitis patients. The mean serum total IgE level and mean serum eosinophil count for the 41 patients who were positive for E. vermicularis eggs and 69 patients in the control group were also presented in Table 1. The difference between two groups was statistically significant for serum total IgE levels $(p<0.05)$, but not for serum eosinophil count $(p>0.05)$. Table 2 presents the pre- and post-treatment serum eosinophil counts and total serum IgE levels of patients with helminth infections and allergic rhinitis. The difference between the groups was statistically significant for serum total IgE level $(p<0.05)$ but not for serum eosinophil count $(p>0.05)$.

Eggs of E. vermicularis were found in 41 $(37.27 \%)$ patients with the sellotape evaluation repeated 3 times. The correlation coefficients between serum total IgE level and eosinophil count are shown in Tables 3 and 4 and the results were statistically insignificant $(p>0.05)$.

Table 2. Pre- and post-treatment IgE level and eosinophil count.

\begin{tabular}{lccc}
\hline & $\begin{array}{c}\text { Pre-treatment } \\
\text { (with } \text { E. vermicularis) }\end{array}$ & $\begin{array}{c}\text { Post-treatment } \\
\text { (with } \text { E. vermicularis) }\end{array}$ & $\boldsymbol{p}$ \\
\hline IgE $(\mathbf{I U} / \mathbf{m L})$ & $393.10 \pm 159.83$ & $228.90 \pm 84.40$ & $<0.05$ \\
Eosinophil $\left(\mathbf{1 0}^{\mathbf{3}} / \mathbf{m L}\right)$ & $0.56 \pm 0.04$ & $0.43 \pm 0.07$ & $>0.05$ \\
\hline
\end{tabular}


Table 3. Pearson correlation of IgE level and eosinophil count

\begin{tabular}{llcc}
\hline & & $\begin{array}{c}\text { IgE } \\
(\mathbf{n = 4 1 )}\end{array}$ & $\begin{array}{c}\text { Eosinophil } \\
(\mathbf{n = 4 1 )}\end{array}$ \\
\hline \multirow{2}{*}{ IgE level } & Pearson Correlation & 1.000 & 0.162 \\
\multirow{2}{*}{ Eosinophil count } & Sig. (2-tailed) & & 0.311 \\
& Pearson Correlation & 0.162 & 1.000 \\
\hline
\end{tabular}

Table 4. Spearman rank test analysis of IgE level and eosinophil count.

\begin{tabular}{llcc}
\hline & & $\begin{array}{c}\text { IgE } \\
(\mathbf{n}=\mathbf{4 1})\end{array}$ & $\begin{array}{c}\text { Eosinophil } \\
(\mathbf{n}=\mathbf{4 1})\end{array}$ \\
\hline \multirow{2}{*}{ IgE level } & Correlation Coefficient & 1.000 & 0.211 \\
& Sig. (2-tailed) & & 0.186 \\
\multirow{2}{*}{ Eosinophil count } & Correlation Coefficient & 0.211 & 1.000 \\
& Sig. (2-tailed) & 0.186 & \\
\hline
\end{tabular}

\section{DISCUSSION}

Increased serum IgE level and eosinophilia are not specific to the allergic diseases. They are also associated with helminth infections [11, 12]. Nowadays, total serum IgE level is a poor indicator of allergic respiratory diseases. High serum IgE levels resulting from polyclonal activation are caused by chronic infection by geohelmints $[13,14]$. Features of helminthic infections are complex in the endemic areas and the immune system response may show individual differences in atopic subjects. Thus, the serum IgE levels may also increase in atopic persons [15].

Geohelmints may also stimulate the release of polyclonal IgE [16]. The helminths, not only increase the production of antiparasite $\operatorname{IgE}$ antibody, but also stimulate polyclonal IgE synthesis, resulting in highly elevated levels of total $\mathrm{IgE}$ in the blood circulation [17]. Although there is some doubt regarding the relationship between helminthic infections and $\operatorname{IgE}$ antibody levels, IgE antibody is an important component of the immune response against parasites [18].

Although helminthic infections are less common in developed countries, atopic diseases are paradoxically more common. Exposure to infections in early childhood decreases the risk of allergy according to the "Hygiene Hypothesis" [19]. Intestinal helminths may decrease polyclonal IgE production in populations with parasitic infection according to this hypothesis [20]. In contrast to the hygiene hypothesis, serum IgE levels of patients with allergic rhinitis only were lower than that of patients with both allergic rhinitis and E. vermicularis infection in our study. However, this may be associated with the duration and severity of these disorders in our patients. Some studies have shown no association between helminth infections and allergic diseases [21]. However, it is reported that parasitic helminths can prevent hyperresponsiveness and eosinophilic airway inflammation in experimental animal models $[22,23]$. In our study we investigated patients with E. vermicularis only and it may be appropriate to study the effects of other parasitic infections as well.

Eosinophils are located in two different regions: tissue and blood. Although the maturation and life of serum eosinophils depend on interleukin-5 (IL-5), the tissue eosinophils depend on granulocyte and macrophage colony stimulating factor (GM-CSF) [24]. Eosinophil count is therefore normal in the blood, but active eosinophils are filled by eosinophil cationic protein, major basic protein, active granules, and other mediators $[24,25]$. The eosinophil levels are normal in some patients since blood eosinophils are down-regulated. The peripheral circulation may not be affected and the inflammatory process may be mild with drug intake and in chronic intestinal parasitic infections [26].

A meta-analysis of the epidemiologic literature by Feary et al. [27] has shown that intestinal parasite infections such as geohelminth infections are related to a reduced prevalence of allergic sensitization. The levels of serum total IgE and eosinophils of allergic rhinitis patients with E. vermicularis infection were higher than in patients with allergic rhinitis only in our 
study, possibly depending on the duration of E. vermicularis infection.

When the intestinal larvae migrate, the eosinophil numbers may decline consequently. Eotaxin is required for chemotaxis [28]. Chronic parasitic infections regulate the immune response and the allergic response is reduced especially in early life. Genetic predisposition to atopy may also provide strong resistance to geohelminth infections. It has been demonstrated that geohelmints may increase the production of specific antibodies [13]. However, the increase in nonspecific polyclonal IgE synthesis and high total IgE levels are directly related to the presence of parasites [14].

The sensitivity of stool examination can be as low as $40 \%$ in some cases. When using the stool examination to evaluate parasite infection, one needs to take into account recurrent anti-helminthic treatment and the small amounts of parasite or the larval forms of the parasite [20]. Nyan et al. [20] found higher serum total IgE concentration in atopic patients than in non-atopic persons. They suggested that atopic individuals are less infected with helminths than nonatopic persons and that atopy could therefore be a protective factor against helminthic infections. High concentrations of non-specific IgE may prevent the invasion of intestinal parasites. They did not find any relationship between serum $\operatorname{IgE}$ concentration and helminth infections.

Since the immune response against parasite infections is variable, mild helminth infections may increase the allergic response in contrast to severe infections [29, 30]. Eosinophilia and elevated serum $\mathrm{IgE}$ are often observed in acute illness as a form of immune response [26]. High serum IgE levels may also trigger eosinophilia.

The helminths can induce suppressor $\mathrm{T}$ cells and lead to a low response against environmental allergens. Interleukin-10 (IL-10) reduces the number of serum eosinophils and also produces transforming growth factor beta (TGF-B) [26]. Production of polyclonal IgE against helminths is a common characteristic in atopic individuals [30]. The host immune response against intestinal helminths is similar to the allergic response. An IgE response is associated with the helminths in children with an atopic predisposition. Helminths and other infectious agents also increase serum IgE levels by increasing the production of non-specific B cells. Wördemann et al. [19] have reported that various relationships are present between helminthic infections and atopic diseases depending on the type of helminth and the allergy.

Lynch et al. [5] reported that a history of a strong $\mathrm{IgE}$ response in atopic children led to an increased protective response against helminths. The infection intensity was significantly lower compared to nonatopic subjects in that study.

The impact of helminths on allergic reactions is occurred in two ways. Nonspecific IgE synthesis may occur in patients with sporadic helminthic infections as a result of stimulation of the immune system and it may increase the allergic sensitivity in these individuals. Mast cell receptors can also be blocked due to excessive polyclonal $\operatorname{IgE}$ development in recurrent infections leading to the inhibition of specific IgE production against allergens [30]. Geller et al. [31] found no difference in serum IgE levels between the patient group and control group. Arıdoğan et al. [32] detected an elevated total $\operatorname{IgE}$ rate of $73.77 \%$ in the group infested with helminths and $35.14 \%$ in the group without helminths. Herrström et al. [33] found E. vermicularis in the 23 of 102 nonallergic control subjects and 26 of 70 allergic patients and the difference was statistically significant $(p=0.037)$.

Ganguly et al. [34] reported that total and specific IgE levels increased in hookworm-infected patients and then decreased significantly after treatment. In the present study, consistent with the literature, a significant decrease in the serum $\operatorname{IgE}$ level after treatment was observed. There was also a decrease in serum eosinophil levels but this was not statistically significant. The results reported in the literature lead to questions about the relationship between parasite infection and allergy. Long-term studies need to be conducted to clearly investigate the causal relationship between helminthic infections and atopic diseases

\section{CONCLUSION}

More comprehensive and long-term placebocontrolled studies should be performed in order to find the answer to the question of whether helminth infections play a role in allergic disease. 


\section{Conflict of interest}

The authors disclosed no conflict of interest during the preparation or publication of this manuscript.

\section{Financing \\ The authors disclosed that they did not receive any grant during conduction or writing of this study.}

\section{REFERENCES}

[1] Medeiros D, Silva AR, Rizzo JA, Motta ME, Oliveira FH, Sarinho ES. Total IgE level in respiratory allergy: study of patients at high risk for helminthic infection. J Pediatr 2006;82:255-9.

[2] Reddy A, Fried B. Atopic disorders and parasitic infections. Adv Parasitol 2008;66:149-91.

[3] Rîpă C, Bahnea RG, Cojocaru I, Luca MC, Ivan A, Luca M. Atopic diseases and intestinal helminth infections. Rev Med Chir Soc Med Nat Iasi 2010;114:1017-21.

[4] Lynch NR, López R, Istfiriz G, Tenías-Salazar E. Allergic reactivity and helminthic infection in amerindians of the amazon basin. Int Arch Allergy Appl Immunol 1983;72:369-72.

[5] Lynch NR, Medouze L, Di Prisco MC, Verde O, López R, Malavé C. Incidence of atopic disease in a tropical environment: partial independence from intestinal helminthiasis. J Allergy Clin Immunol 1984;73:229-33.

[6] Levin ME, Le Souëf PN, Motala C. Total IgE in urban Black South African teenagers: the influence of atopy and helminth infection. Pediatr Allergy Immunol 2008;19:449-54.

[7] Wardlaw AJ. Eosinophils in 1990s: new perspectives on their role in health and disease. Postgrad Med 1994;70:536-52.

[8] Cook GC. Enterobius vermicularis infection. Gut 1994;35:1159-62.

[9] Hood C. Enterobius vermicularis. Practitioner 1989; 233:503.

[10] Bousquet J, Khaltaev N, Cruz AA, Denburg J, Fokkens WJ, Togias A, et al; World Health Organization, GA(2)LEN and AllerGen. Allergic Rhinitis and its Impact on Asthma (ARIA) 2008 uptade(in collaboration with the World Health Organization, GA(2)LEN and AllerGen). Allergy 2008;63(suppl 86):8-160.

[11] Arruda LK, Santos AB. Immunologic responses to common antigens in helminthic infections and allergic disease. Curr Opin Allergy Clin Immunol 2005;5:399-402.

[12] Schneider M, Hilgers RH, Sennekamp J. Allergy, total IgE and eosinophils in East and West. Serious effects of different degrees of helminthiasis and smoking. Eur J Med Res 2002;21:63-71.

[13] Cooper PJ, Chico ME, Rodrigues LC, Ordonez M, Strachan D, Griffin GE, et al: Reduced risk of atopy among school-age children infected with geohelminth parasites in a rural area of the tropics. J Allergy Clin Immunol 2003; 111:995-1000.

[14] Sales VS, Rodrigues CE, Cavalcanti GB, Trombone APF, Lima RC, Santos ABR, et al. Infection with Ascaris lumbricoides in preschool children: role in wheezing and IgE responses to inhalant allergens. J Allergy Clin Immunol 2002;109:S27.

[15] Bell RG. IgE, allergies and helminth parasites: a new perspective on an old conundrum. Immunol Cell Biol 1996;74:337-45.

[16] Scrivner S, Yemaneberhan H, Zebenigus M, Tilahun D, Girma S, Ali S, et al. Independent effects of intestinal parasite infection and domestic allergen exposure on risk of wheeze in Ethiopia: a nested casecontrol study. Lancet 2001;358:1493-9.

[17] Lynch NR, Hagel IA, Palenque ME, Di Prisco MC, Escudero JE, Corao LA, et al. Relationship between helminthic infection and IgE response in atopic and nonatopic children in a tropical environment. $\mathrm{J}$ Allergy Clin Immunol 1998;101:217-21.

[18] Allen JE, Maizels RM. Immunology of human helminth infection. Int Arch Allergy Immunol 1996;109:3-10.

[19] Wördemann M, Diaz RJ, Heredia LM, Collado Madurga AM, Ruiz Espinosa A, Prado RC, et al. Association of atopy, asthma, allergic rhinoconjunctivitis, atopic dermatitis and intestinal helminth infections in Cuban children. Trop Med Int Health 2008;13:180-6.

[20] Nyan OA, Walraven GE, Banya WA, Milligan P, Van Der Sande M, Ceesay SM, et al. Atopy, intestinal helminth infection and total serum IgE in rural and urban adult Gambian communities. Clin Exp Allergy 2001;31:1672-8.

[21] Lynch NR, Hagel I, Perez M, Di Prisco MC, Lopez R, Alvarez N. Effect of anthelmintic treatment on the allergic reactivity of children in a tropical slum. J Allergy Clin Immunol 1993;92:404-11.

[22] Smits HH, Hammad H, van NM, Soullie T, Willart MA, Lievers E, et al: Protective effect of Schistosoma mansoni infection on allergic airway inflammation depends on the intensity and chronicity of infection. J Allergy Clin Immunol 2007;120:932-40.

[23] Amu S, Saunders SP, Kronenberg M, Mangan NE, Atzberger A, Fallon PG: Regulatory B cells prevent and reverse allergic airway inflammation via FoxP3-positive T regulatory cells in a murine model. J Allergy Clin Immunol 2010;125:1114-24.

[24] Alan R. Busse WW. The eosinophil, quo vadis? J Allergy Clin Immunol 2004;113:38-42.

[25] Martin LB, Kita H, Eiferman K, Gleich GJ. Eosinophils in allergy: role in disease, degranulation, and cytokines. Int Arch Allergy Immunol 1996;109:207-15.

[26] Klion AD, Nutman TB. The role of eosinophil in host defense against helminth parasites. J Allergy Clin Immunol 2004;113:30-7.

[27] Feary J, Britton J, Leonardi-Bee J. Atopy and current intestinal parasite infection: a systematic review and meta-analysis. Allergy 2011;66:569-78.

[28] Lima C, Perini A, Garcia ML, Martins MA, Teixeira MM, Macedo MS. Eosinophilic inflammation and airway hyper-responsiveness are profoundly inhibited by a helminth (Ascaris suum) extract in a murine model of asthma. Clin Exp Allergy 2002;32:1659-66.

[29] Lynch NR, Hagel I, Vargas V, Pérez M, López RI, Garcia NM, et al. Effect of age and helminthic infection on $\operatorname{IgE}$ levels in slum children. J Invest Allergol Clin Immunol 1993;3:96-9.

[30] Hagel I, Lynch N, Pérez M, Di Prisco MC, López R, Rojas E. Modulation of the allergic reactivity of slum children by helminthic infection. Parasite Immunol 1993;15:311-5.

[31] Geller M, Geller M, Flaherty DK, Black P, Madruga M. Serum IgE levels in giardiasis. Clin Allergy 1978;8: 69-71.

[32] Arıdoğan BC, Demirci M. Çocuklarda bağırsak parazitleri ve serum total IgE düzeyleri arasındaki ilişkinin incelenmesi. T Parazitol Derg 2001;25:346-8.

[33] Herrström P, Henricson KA, Råberg A, Karlsson A, Högstedt B. Allergic disease and the infestation of Enterobius vermicularis in Swedish children 4-10 years of age. J Investig Allergol Clin Immunol 2001;11:157-60.

[34] Ganguly NK, Mahajan RC, Sehgal R, Shetty P, Dilawari JB. Role of specific immunglobulin $\mathrm{E}$ to excretory-secretory antigen in diagnosis and prognosis of hookworm infection. J Clin Microbiol 1988;26:73942 . 